\title{
Kreativitas Mang Koko Dalam Karawitan Sunda
}

\author{
Tardi Ruswandi \\ Program Doktor Universitas Padjadjaran Bandung \\ Jln. Raya Bandung Sumedang Km. 21, Jatinangor 45363 \\ Promotor: \\ Prof. Dr. H. Dadang Suganda, M.Hum. \\ Prof. Dr. Ir. H. Ganjar Kurnia \\ Prof. Dr. Endang Caturwati
}

\begin{abstract}
The focus of this study is on Mang Koko's creativities in composing songs and gending as a counterpoint. Mang Koko's creativities are then analyzed by Supriadi's theory (1994: 7) which explains that creativity is a person's ability to create something new, either in the form of ideas and real works. Mang Koko was one of creative and prolific artists whose creations are still taken into consideration. In developing and creating new genre of Karawitan Sunda, Mang Koko had been indeed inspired by some kind of Karawitan Sunda and the patterns of Western music so that his creative process was really based on the aspects of intensification and composition. The results of Mang Koko's creativities had been grouped into Sekar Jenaka, Kawih songs (anggana dan rampak sekar), Gamelan Wanda Anyar, Kacapian, Etude Kacapi, and Drama Suara (Gending Karesmen).
\end{abstract}

Key Word: Mang Koko, Kreativitas, Karawitan Sunda

\begin{abstract}
ABSTRAK
Penelitian ini terfokus pada kreativitas Mang Koko dalam menciptakan lagu-lagu dan gending sebagai pengiring lagu. Kreativitas Mang Koko dianalisis dengan menggunakan teori Dedi Supriadi (1994:7) yang menjelaskan bahwa kreativitas merupakan kemampuan seseorang untuk melahirkan sesuatu yang baru, baik berupa gagasan maupun karya nyata, yang relatif berbeda dengan apa yang telah ada sebelumnya. Mang Koko merupakan seniman kreatif dan produktif dalam berkarya yang hingga saat ini masih diperhitungkan. Dalam mengembangkan karawitan Sunda dan melahirkan genre baru, Mang Koko terilhami oleh beberapa jenis karawitan Sunda dan terinspirasi oleh pola-pola musik Barat sehingga proses kreatifnya berpijak pada aspek penggalian dan penciptaan. Hasil kreativitas Mang koko dikelompokkan menjadi Sekar Jenaka, lagu-lagu Kawih (anggana dan rampak sekar), Gamelan Wanda Anyar, Kacapian, Etude Kacapi, dan Drama Suara (Gending Karesmen).
\end{abstract}

Kata kunci: Mang Koko, Kreativitas, Karawitan Sunda 


\section{PENDAHULUAN}

Mang Koko yang nama lengkapnya $\mathrm{H}$. Koko Koswara, lahir di Indihiang Tasikmalaya, Provinsi Jawa Barat (Indonseia), pada tanggal 24 November 1915. Akan tetapi pada waktu masuk sekolah formal, kelahirannya dirubah menjadi 10 April 1917 (Tatang Sumarsono, dalam Tardi, 2007:3). Dalam lingkungan keluarganya, Mang Koko merupakan anak tunggal dari pasangan suami istri Mochamad Ibrahim dengan Siti Hasanah. Sedangkan pendidikan formal yang ditempuh Mang Koko adalah HIS (Holands Inlandsche School) setingkat dengan Sekolah Dasar (SD), lulus dan berizasah 1932 serta MULO (Meer Uitgebruid Lager Onderwjs) setingkat dengan Sekolah Menengah Pertama (SMP), lulus dan berizasah 1936.

Pekerjaan yang pernah dilalui Mang Koko selama hidupnya adalah sebagai berikut: Pertama, Mang Koko bekerja sebagai karyawan Bale Pamoelangan Pasoendan (Paguyuban Pasundan) bagian pendidikan. Kedua, pada tahun 1940 ia memilih bekerja di sebuah Bank yang bernama 'De Javasche Bank'. Ketiga, pada tahun 1942, Mang Koko pindah lagi menjadi pengurus advertensi (iklan) di Harian Cahaya Shimbun. Keempat, pada tahun 1945, ia bekerja sebagai administratur Harian Suara Merdeka Bandung, dan pada zaman revolusi, harian tersebut pindah ke Tasikmalaya. Kelima, pada tahun 1950 hingga tahun 1961, Mang Koko bekerja di Jawatan Penerangan Propinsi Jawa Barat. Keenam, pada tahun 1959, ketika Mang Koko masih bekerja di Jawatan Penerangan, ia bersama-sama dengan temannya mendirikan dan sekaligus memimpin Yayasan Cangkurileung yang tersebar hampir di seluruh Kabupaten dan Kotamadya se Jawa Barat. Anggotanya anak-anak sekolah dasar dan menengah. Ketujuh, pada tahun 1961
Mang Koko mengajar di KOKAR (SMKI) Bandung, bahkan selama 6 tahun hingga pensiun (1966-1972) ia menjadi direkturnya. Kedelapan, ketika Mang Koko memimpin KOKAR, pada tahun 1971 ia mendirikan ASKI (Akademi Seni Karawitan Indonesia) swasta, yang merupakan cerminan ketidaksabarannya menantikan kehadiran pendidikan tinggi karawitan negeri. Pada waktu itu, Mang Koko dipercaya sebagai direkturnya. Kesembilan, pada tahun 1974 yaitu setelah pensiun dari KOKAR Bandung, Mang

Koko diangkat menjadi dosen Luar Biasa dan sekaligus diberi tugas sebagai ketua Jurusan Karawitan ASTI Bandung, yang sesungguhnya merupakan hasil integrasi antara ASKI dan ASTI Bandung. Melalui pendidikan seni formal inilah, Mang Koko berharap agar ke depan para seniman harus bergelar sarjana, bukan bergelar 'Mang' seperti dirinya. Harapan Mang Koko tersebut akhirnya menjadi kenyataan, sehingga sekarang ini tingkat pendidikan seniman bukan saja sarjana, melainkan juga Magister dan Doktoral.

Berdasarkan jenisnya karya-karya Mang Koko sebagai hasil kreativitasnya dalam mengembangkan karawitan Sunda, terdiri atas: Sekar Jenaka, lagu-lagu Kawih (anggana dan rampak sekar), Gamelan Wanda Anyar, Kacapian, Etude Kacapi, dan Drama Suara atau Gending Karesmen. Karya-karya Mang Koko tersebut, sekalipun dibuat baru, tetapi secara esensial masih mengakar pada karawitan tradisional, sehingga secara musikal karya tersebut masih bernuansa karawitan Sunda.

Terciptanya karya baru Karawitan Sunda dalam konteks kehidupan sosial, secara mendasar disebabkan karena adanya kebutuhan baik untuk diri sendiri, maupun untuk masyarakat pada umumnya. Terciptanya Karawitan Sunda yang ber-dasar 
pada kebutuhan diri sendiri, selain seniman ingin mengaktualisasikan penga-laman estetisnya, juga karena seniman ingin eksis di lingkungan sosialnya. Sementara itu, terciptanya Karawitan Sunda yang berdasar pada kebutuhan masyarakat umum, karena para seniman membaca gejala sosial, yang secara sadar mereka memerlukan karya seni sesuai dengan seleranya. Oleh sebab itu, para seniman yang kreatif selalu cerdik membaca dan menyikapi perkembangan zaman dengan melahirkan karya-karya seni sesuai dengan selera masyarakat pada zamannya.

\section{METODE}

Permasalahan yang dikaji dalam penelitian ini, lebih cenderung pada kreativitas Mang Koko dalam mengembangkan karawitan Sunda, khususnya dalam penggalian dan penciptaan seni karawitan. Oleh sebab itu, metode yang digunakannya adalah metode kualitatif (J. Moleong, 1990), yaitu 'memahami fakta yang ada di balik kenyataan melalui pengamatan atau peninjauan secara langsung di lapangan'. Metode lainnya yang juga menunjang pada konsep penggalian dan penciptaan adalah metode komparatif, karena dalam membahas kreativitas Mang Koko tidak lepas dari karawitan tradisi sebagai pijakannya. Kedua metode ini diharapkan dapat menjelaskan semua permasalahan yang diteliti.

\section{PEMBAHASAN}

Dalam hal kreativitas, Mang Koko dapat dikatakan pelopornya. Hal ini disebabkan karena Mang Koko telah banyak menularkan konsep kreativitas kepada seniman generasi berikutnya, dalam arti karya-karya Mang Koko sebagai hasil kretivitasnya, kebanyakan dijadikan pijakan oleh para seniman generasi penerus ketika membuat karya baru karawitan. Atas dasar hal itu, Mang Koko menjadi figur seniman yang patut dicontoh kreativitas dan kenerjanya dalam mengembangkan karawitan Sunda. Dalam pembahasan kreativitas, penulis menggunakan kreativitas pendapat Dedi Supriadi. Kaitannya dengan karawitan Sunda, kreativitas adalah kemampuan seniman dalam melahirkan karya karawitan yang berbeda dengan karya karawitan sebelumnya. Untuk itu dalam mengungkap Kretivitas Mang Koko dalam Karawitan Sunda, dapat dilakukan dengan menjelaskan penggalian dan penciptaan yang dilakukan Mang Koko.

\section{A. Penggalian}

Penggalian adalah menggali kemampuan fisik untuk mengekspresikan karyakarya estetis secara optimal. Wujud kreativitas Mang Koko melalui penggalian yang dianggap menonjol dalam karawitan Sunda, secara fisik terealisasi melalui keterampilan tangan dan vokal.

\section{Keterampilan Tangan}

Eksplorasi Mang Koko dalam keterampilan tangan adalah mendinamisasikan permainan Kacapi Siter dan Gamelan pelogsalendro dengan cara menggali kemungkinan-kemungkinan kemapuan tangan, dalam wilayah nada pada waditra ke dalam suatu bentuk sajian musik pengiring vokal dan musik instrumenal. Untuk memahami Mang Koko melakukan penggalian dalam karawitan Sunda, penulis jelaskan melalui instrumen kacapi siter dan gamelan pelogsalendro.

\section{a. Penggalian Melalui Kacapi Siter}

Penggalian Mang Koko melalui kacapi siter secara substansial prosesnya berorien-tasi pada permainan kacapi garap Jenakaan Menir Muda dan garap Kacapi Cianjuran. Eksplorasi Mang Koko dalam hal ini adalah mendinamisasikan permainan kacapi, dengan cara 
memfungsikan 7 jari tangan (kiri dan kanan) dari yang biasanya hanya 2 (dua) sampai dengan 4 (empat) jari. Selain itu Mang Koko juga mengembangkan teknik permainan kacapi yang asalnya 3 (tiga) macam menjadi 5 (lima) macam. Untuk keperluan tersebut wilayah nada pun diperluas, sehingga yang biasanya dalam satu permainan kacapi mengguna-kan 5 sampai 13 nada dari 18 nada, dalam permainan kacapi Mang Koko menjadi seluruhnya digunakan. Bahkan untuk kepentingan komposisinya Mang Koko menambah 2 nada, sehingga seluruh nada pada senar kacapi menjadi 20 nada. Jadi penggalian Mang Koko dari permainan kacapi gaya tradisi untuk iringan vokal adalah memfungsikan jari tengah dan jari manis, dengan teknik petikan diawali oleh jari tengah kanan, sehingga menghasilkan permainan kacapi yang berbeda dengan sebelumnya, dan lebih rumit bila dibandingkan dengan permainan kacapi tradisi.

Dalam hal teknik permainan kacapi yang semula hanya 3 macam yaitu sintreuk-toel ${ }^{1}$, dijeungkalan ${ }^{2}$, dan beulit $k_{\text {kacang }}{ }^{3}$, Mang Koko kembangkan menjadi 5 macam dengan teknik diranggeum ${ }^{4}$ dan teknik dijambret ${ }^{55}$. Perbedaan antara teknik yang satu dengan lainnya adalah penjarian (penempatan jari) berikut jumlah nada yang dihasilkan dari jari-jari tangan. Hasil penggalian melalui kacapi, Mang Koko dapat melahirkan cara memainkan kacapi yang khas, sehingga dalam konteks perkembangan karawitan Sunda dapat dikategorikan sebagai permainan kacapi gaya Mang Koko. Sebagai gambaran, permainan kacapi gaya tradisi dan gaya Mang Koko seperti berikut ini:

Permainan kacapi teknik sintreuk-toel gaya tradisi dengan 1 (satu) jari tangan kanan (disintreuk) dan 1 (satu) jari tangan kiri (ditoel).

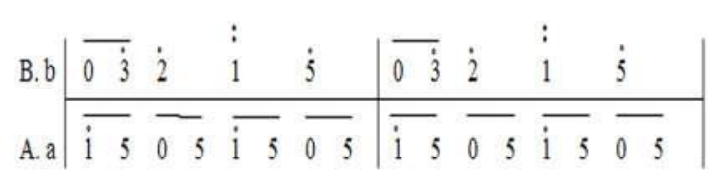

Permainan kacapi teknik dijeungkalan gaya tradisi, dengan 2 (dua) jari tangan kanan dan 2 (dua) jari tangan kiri.

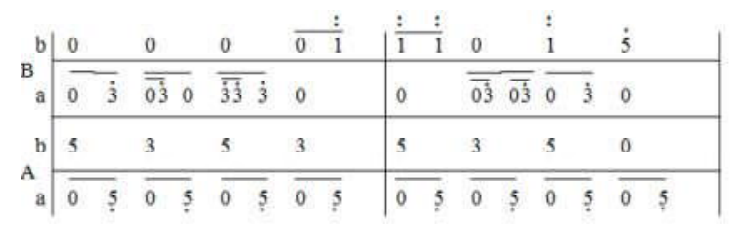

Permainan kacapi teknik beulit kacang gaya tradisi, dengan 2 (dua) jari tangan kanan dan 1 (satu) jari tangan kiri.

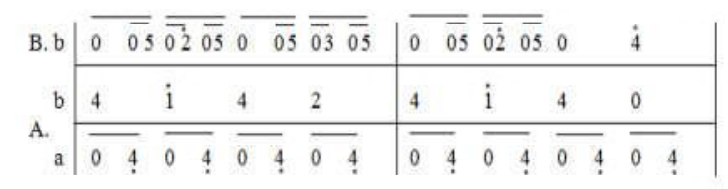

Permainan kacapi teknik diranggeum gaya Mang Koko, dengan menggunakan 4 (empat) jari tangan kanan dan 2 (dua) jari tangan kiri.

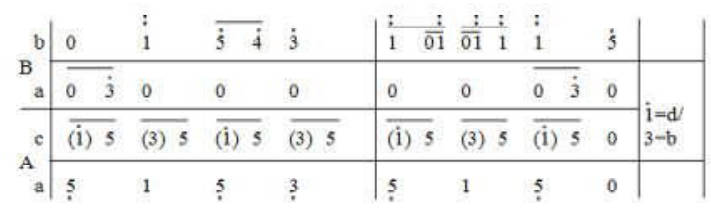

Untuk nada yang diberi tanda kurung, seperti nada 1 (da) rendah pada melodi jari c (jari tengah) maka nada 1 (da) rendah dibunyikan dengan jari d (jari manis), nada 3=b yaitu nada 3 (na) dibunyikan dengan jari b (telunjuk).

Permainan kacapi teknik dijambret gaya Mang Koko, dengan menggunakan 3 (tiga) jari tangan kanan dan 2 (dua) jari tangan kiri. 


\begin{tabular}{|c|c|c|c|c|c|c|c|c|c|c|c|c|}
\hline & & : & & & & ; & & & : & & & : \\
\hline b & 0 & 5 & & 0 & & 5 & 0 & & 5 & & 0 & \\
\hline B. & $!$ & & & : & & & : & & & & ! & \\
\hline a & 2 & 0 & & 2 & & 0 & 2 & & 0 & & 2 & 0 \\
\hline c & 0 & 0 & 5 & 0 & & $\begin{array}{ll}0 \quad 5 \\
\end{array}$ & 0 & 5 & 0 & 5 & 05 & 0 \\
\hline A. b & 0 & 0 & 2 & 0 & & $0 \dot{2}$ & 0 & 2 & 0 & 2 & $\overline{02}$ & 0 \\
\hline a & 0 & 0 & & 0 & & 5 & 0 & 5 & & & & 0 \\
\hline
\end{tabular}

Penggalian Mang Koko dari permainan kacapi tradisi untuk mengiringi vokal seperti yang telah dicontohkan pada gaya diranggeum adalah memfungsikan telunjuk (b) dan jari manis (d) tangan kanan, sehingga menghasilkan permainan kacapi yang lebih rumit bila dibandingkan dengan permainan kacapi gaya tradisi. Karena ide ini datangnya dari Mang Koko, maka masyarakat menyebutnya kacapi gaya Mang Koko.

Teknik permaian kacapi gaya Mang Koko yang diranggeum merupakan pengembangan dari teknik dijeungkalan. Hal ini terlihat dari penjarian tangan kanannya yang merupakan perpaduan dua buah nada secara bersahutan seperti yang dibunyikan ibu jari dan jari tengah pada contoh teknik dijeungkalan. Di samping itu penjarian teknik dijeungkalan, yang semula hanya dengan 4 jari tangan (kanan dan kiri), Mang Koko kembangkan hingga menjadi 5 sampai 6 jari tangan (kiri dan kanan). Sedangkan teknik dijambret merupakan penggalian dari musik iringan lagu-lagu mars (lagu yang bertempo cepat dan gagah). Dalam teknik ini Mang Koko menyajikan nada-nada harmonis sebanyak tiga buah yang dimainkan oleh tiga jari tangan kanan secara bersamaan seperti akor (accord) dalam musik Barat.

\section{b. Penggalian Melalui Gamelan Pelog- Salendro}

Penggalian Mang Koko melalui gamelan pelog-salendro, prosesnya sebagai berikut: menabuh gamelan secara melodis ber- pedoman pada teknik permainan gamelan salendro dalam garapan Wayang Golek Purwa, terutama gending-gending yang disajikan pada waktu Tataluan. Kerasnya menabuh gamelan terpengaruh oleh permainan gamelan Bali. Sedangkan teknik menabuh kemprangan dan carukan diambil dari garap kiliningan (gamelan tradisi). Eksplorasi Mang Koko dalam hal ini, memfungsikan beberapa waditra yang dapat tampil sebagai pembawa melodi; memperluas wilayah nada di dalam satu permainan waditra; menambahkan teknik tabuhan dari 3 macam menjadi 5 macam $(3+2)$; membuat gending berdialog; dan memberlakukan dinamika seperti pada permainan gamelan Bali.

Apabila disusun, penggalian Mang Koko dalam permainan gamelan melalui keterampilan tangan, adalah sebagai berikut:

1) Memfungsikan waditra bonang dan rincik sebagai pembawa melodi di dalam sekar gending yang sebelumnya jarang sekali dilakukan. Contoh permainan Bonang dan Rincik seperti di bawah ini.

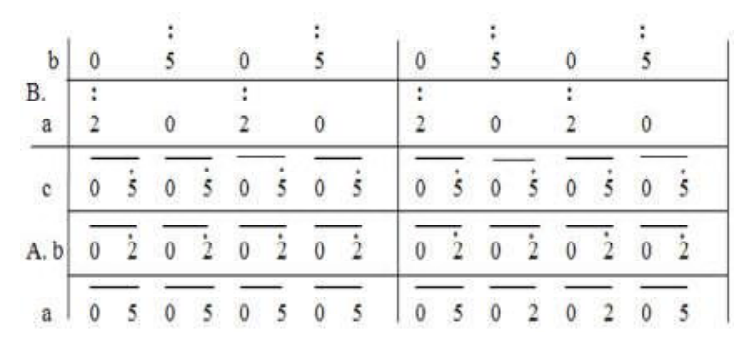

2) Memperluas wilayah nada di dalam satu permainan waditra, misalnya permainan bonang yang biasanya paling banyak 6 (enam) dari 10 atau 12 nada, menjadi 8 (delapan) nada atau lebih. Contoh permainan Bonang gaya Mang Koko baik gamelan Pelog maupun Salendro, seperti di bawah ini. 


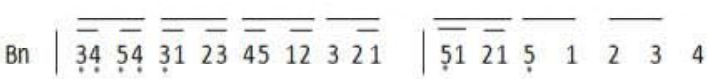

3) Menambah teknik menabuh waditra gamelan, dari 3 macam menjadi 5 macam, yaitu dicaruk ${ }^{6}$, dikemprang ${ }^{7}$, dibalung $^{8}$ (tradisi), ditambah dicacag ${ }^{9}$ dan dikeleter. . Salah satu contoh teknik dicaruk (carukan) seperti di bawah ini.

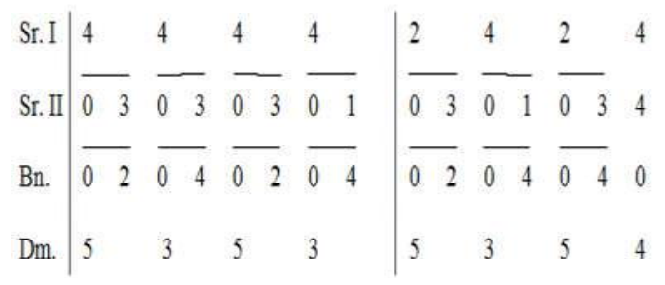

4) Mengembangkan komposisi nada pada gamelan dengan membuat 'gending berdialog' dari biasanya 'gending penuh'. Salah satu contoh gending berdialog antara waditra yang satu dengan lainnya seperti di bawah ini.

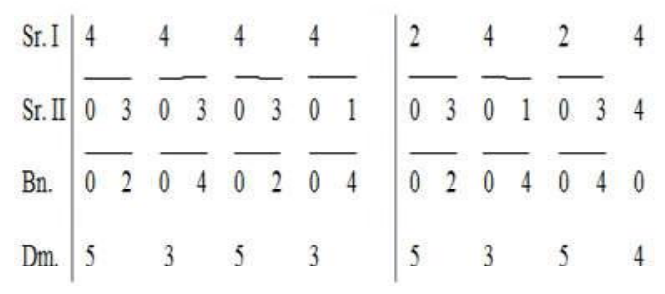

Kreativitas Mang Koko dalam gamelan, sebagai hasil dari penggalian tersebut, dapat menghasilkan permainan gamelan warna baru yang memuat unsur melodis, tematis, dramatis, teknis, dan komunikatif, sehingga diberi istilah gamelan wanda anyar.

\section{Keterampilan berolah vokal}

Penggalian Mang Koko melalui keterampilan Vokal, proses pembentukannya sebagai berikut: untuk teknik olah vokal ${ }^{11}$, bertitik tolak dari kegiatan rutin 'tarhim'12 ketika Mang Koko masih berada di tempat kelahirannya; untuk kesederhanaan melodi vokal berpedoman pada Tembang Pupuh ${ }^{13}$; untuk vibrasi salendro dan surupan tinggi berpijak pada Tembang Ciawian ${ }^{14}$; untuk ornamen (hiasan lagu) dan melodi lagu yang sulit, berpijak pada Tembang Cianjuran ${ }^{15}$ dan Kawih Kepesindenan ${ }^{1616}$

Eksplorasi Mang Koko dalam keterampilan berolah vokal di antaranya: membuat lagu sederhana untuk tingkat usia sekolah dasar dan menengah, membuat lagu yang melodinya sulit untuk tingkat dewasa dan orang tua, membuat lagu berdialog dari lagu yang biasanya selalu penuh (tanpa ada unsur dialog) dan membuat lagu tiga suara dari lagu yang pada umumnya hanya satu atau dua suara. Dalam membuat lagu yang berdialog Mang Koko membuat lagu baru yang di dalamnya mengandung unsur-unsur dialog. Berdasarkan penyajiannya lagu berdialog karya Mang Koko terdiri atas lagu dan dialog serta dialog dalam bentuk lagu. Lagu dan dialog artinya lagu yang dilengkapi dialog tanpa dinyanyikan dan tanpa iringan. Sedangkan dialog dalam bentuk lagu ialah dialog yang teksnya disesuaikan dengan kebutuhan lagu.

Eksplorasi berikutnya, Mang Koko membuat lagu tiga suara, yang dalam istilah lain disebut Layeutan Swara yaitu perpaduan tiga suara dalam sebuah lagu, yang alur melodinya kadang-kadang ada yang sama dan ada yang berbeda, tetapi bila disajikan ketiga suara tersebut menjadi harmonis. Salah satu contohnya dialog dalam bentuk lagu seperti pada lagu Pameget Cegekan di bawah ini. 


\section{Pameget Cegekan}

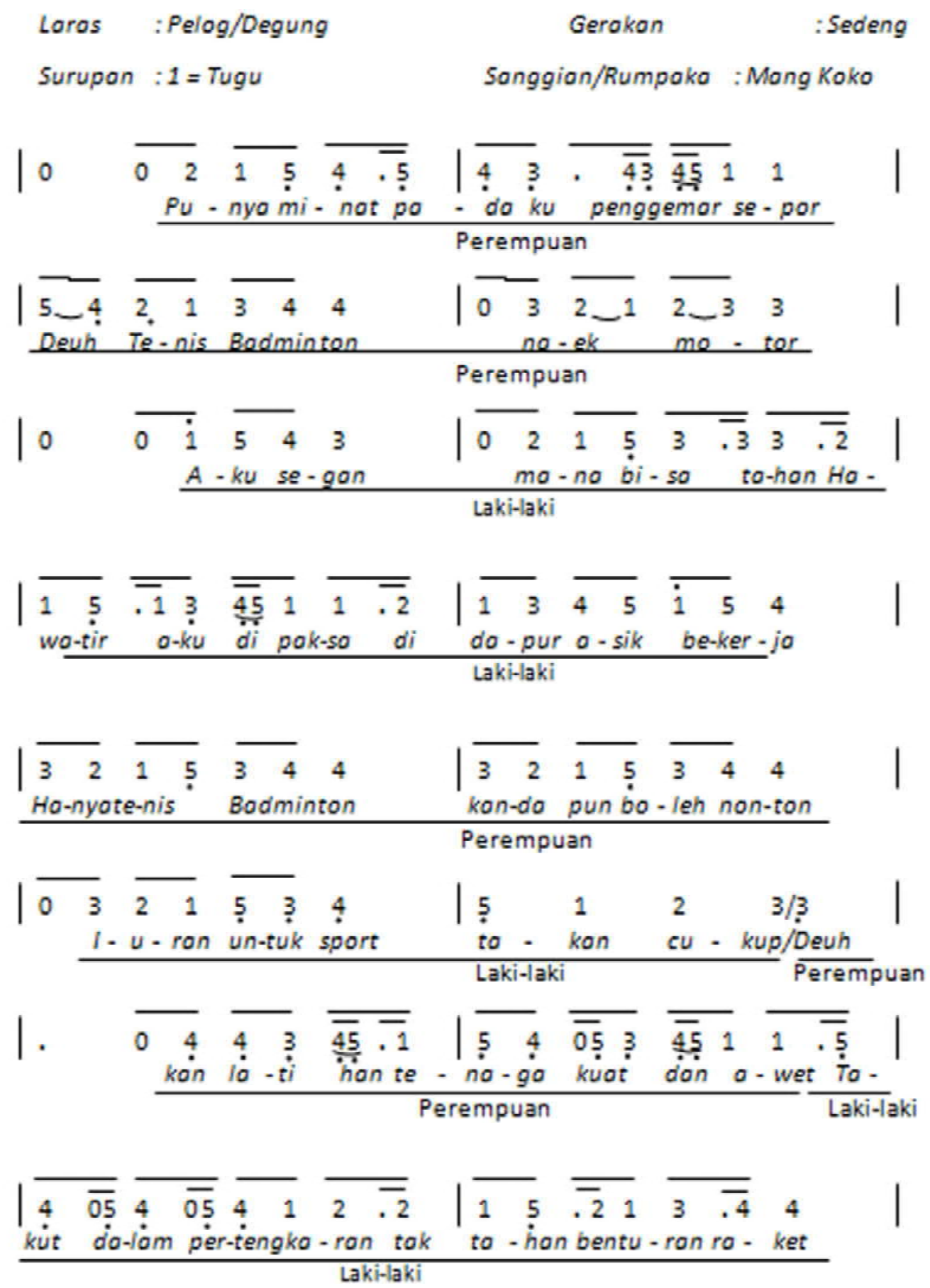


Penggalian Mang Koko dalam lagu Pameget Cegekan, berupa susunan melodi lagu yang sifatnya dialog antara Laki-laki dan Perempuan. Oleh sebab itu, karyakarya vokal Mang Koko secara umum melahirkan lagu-lagu yang sederhana, sedang, dan yang sulit, sehingga dengan kata lain disebut lagu-lagu kawih Mang Koko-an.

\section{B. Penciptaan}

Mang Koko termasuk salah seorang seniman yang produktif dalam membuat lagu. Seluruh ciptaannya tidak kurang dari 398 buah; baik vokal (sekar) maupun instrumenal (gending). Ada beberapa hal yang mendorong Mang Koko untuk membuat karya, di antaranya adalah respon terhadap situasi lingkungan, ingin menampilkan karya baru karawitan, ingin mendidik generasi penerus, dan hasrat mengekpresikan rasa estetis secara murni.

\section{Membuat Karya atas Respon Terhadap Situasi Lingkungan}

Karya Mang Koko yang didasari atas dorongan respon terhadap situasi lingkungan akan dilacak lewat karya vokal (lagu) dengan memperhatikan tahun penciptaan serta kesesuaian isi lirik dengan situasi sosal, politik,dan budaya pada waktu itu.

Dalam situasi sosal, yaitu ketika gerakan koperasi baru gencar disosialisasikan oleh pemerintah, Mang Koko membuat lagu dengan judul 'Koperasi'. Lagu ini dibuat bertepatan dengan Hari Koperasi sekitar tahun 1953.

Mang Koko mengakui bahwa lirik Koperasi yang dibuatnya tidak berdasarkan kepada pengetahuan berkoperasi. Bahkan bertanya pun tidak sempat dilakukannya (Eka Gandara, wawancara 20 Juni 2015). Oleh sebab itu, hal-hal yang berhubungan dengan koperasi hanya terungkap berdasarkan pengetahuan berkoperasi yang dimilikinya. Untuk mengetahui sampai sejauh mana pemahaman Mang Koko tentang koperasi dapat dilihat pada lirik lagu di bawah ini.

\begin{tabular}{|c|c|}
\hline Lirik & Lirik \\
\hline $\begin{array}{l}\text { a. Koperasi-koperasi } \\
\text { Reugreug pageuh } \\
\text { jujur jembar pangurusna } \\
\text { Sampuma organisasi } \\
\text { Ngitung tabah tur catetna tur bukuna }\end{array}$ & $\begin{array}{l}\text { e. Tangtuna geus dirarancang } \\
\text { Koperasi bakal ngatur } \\
\text { Mere nginjeum duit modal } \\
\text { Ka si leutik nu keur nganggur }\end{array}$ \\
\hline $\begin{array}{l}\text { b. Koperasi-koperasi } \\
\text { Nyimpen duit } \\
\text { tetep mayeng unggal bulan } \\
\text { Tong kapohoan, masing maranti } \\
\text { Unggal waktu jeung nyengcelengan }\end{array}$ & $\begin{array}{l}\text { f. Rek jadi tentara sieun ku mortir } \\
\text { Jadi supir teu boga reboes } \\
\text { Nyerepan film ster teu boga dasi } \\
\text { Mun nganggur nagara rugi } \\
\text { (kembali ke c) }\end{array}$ \\
\hline $\begin{array}{l}\text { c. Tinimbang pake awuntah } \\
\text { Duit dipake teu uni } \\
\text { Mending diatur sing tabah } \\
\text { Disimpen di koperasi }\end{array}$ & $\begin{array}{l}\text { g. Hayang sare tibra teu boga imah } \\
\text { Los ka hotel. harus bayar kontan } \\
\text { Milu jeung mitoha sok gegelendeng } \\
\text { Reknyewa euweuh wang konci }\end{array}$ \\
\hline $\begin{array}{l}\text { d. Cari pekerjaan euweuh diploma } \\
\text { Arek tani sawah henteu boga } \\
\text { Jadi tukang copet sieun pulisi } \\
\text { Mun nganggur nagara rugi }\end{array}$ & $\begin{array}{l}\text { h. Koperasi kahareupan } \\
\text { Ngararancang perumahan } \\
\text { Keurngaraksa jeung nulungan } \\
\text { Ra'yat nu katalangsara }\end{array}$ \\
\hline
\end{tabular}


a. Mari-mari sigap gulung tangan Mari mari nyusun persiapan Giat tandak, sorak rampak Nyongsong Pemilihan Umum b. Indonesia bentuk Negri demokrasi

Milih wakil bisik ati sanubari

Pilih Satria Dewa Ampera

Siap dan Waspada, Nyongsong Pemilihan Umum
Lirik lagu tersebut pada dasarnya menghimbau masyarakat agar menyimpan sebagian uangnya di koperasi. Hal ini menunjukkan bahwa terciptanya lagu Koperasi dalam rangka ikut serta menyemarakkan (mensosialisasikan) program pemerintah, lewat karya vokal. Lirik yang digambarkan Mang Koko adalah harapan di masa datang bahwa koperasi dapat mengatur dalam memberi pinjaman modal dan kredit perumahan bagi para anggotanya. Berkaitan dengan hal ini, Mang Koko hanya mengungkapkan bahwa koperasi itu merupakan organisasi yang dapat mengelola dan mengatur uang simpanan masyarakat yang menjadi anggota. Dengan uang tersebut, ke depan dapat membantu meningkatkan kesejahteraan para anggotanya.
Dalam situasi politik, Mang Koko merespon keadaan menjelang Pemilu (Pemilihan Umum) tahun $1971{ }^{18}$ dengan membuat lagu yang berjudul Pemilihan Umum. Lagu ini dibuat tahun 1970-an yaitu ketika partai politik (PPP, Golkar, dan PDI) hangat mempersiapkan Pemilu dalam rangka mencari dukungan suara untuk partainya masing-masing. Adapun liriknya sebagai berikut:

Lagu tersebut dibuat Mang Koko dalam rangka ikut serta menyambut pesta demokrasi (Pemilu). Isi lirik lagunya mengajak masyarakat untuk bersiap-siap menyambut Pemilihan Umum serta menghimbau agar memilih wakil-wakil mereka didasari oleh dorongan hati nuraninya masing-masing (tidak dipengaruhi oleh orang lain).

\begin{tabular}{|c|c|c|c|}
\hline No. & Lirik & No. & Lirik \\
\hline a. & $\begin{array}{l}\text { Allohu Akbar, Allohu Akbar } \\
\text { Allohu Akbar, walilla ilham }\end{array}$ & a & $\begin{array}{l}\text { Allohu Akbar, Allohu Akbar } \\
\text { Allohu Akbar, walilla ilham }\end{array}$ \\
\hline b. & $\begin{array}{l}\text { Ngucapkeun alhamdulilah } \\
\text { Cacap nyumponan ibadah } \\
\text { Puasa jeung Jakat-Fitrah } \\
\text { Iklas rido kema Allah }\end{array}$ & e. & $\begin{array}{l}\text { Awoma aneka rasa } \\
\text { Seuri jeung rambay cimata } \\
\text { Kumia ti nu kawasa } \\
\text { Ni'mat bari jeung nalangsa }\end{array}$ \\
\hline c. & $\begin{array}{l}\text { Lebaran datang, } \\
\text { Minal aidzin walfaidzin } \\
\text { Umat Islam silih rangkul } \\
\text { Haksama pasusul-pasusul }\end{array}$ & f. & $\begin{array}{l}\text { Lebaran datang, } \\
\text { Minal aidzin walfaidzin } \\
\text { Umat Islam silih rangkul } \\
\text { Haksama pasusul-pasusul }\end{array}$ \\
\hline a. & $\begin{array}{l}\text { Allohu Akbar, Allohu Akbar } \\
\text { Allohu Akbar, walilla ilham }\end{array}$ & a. & $\begin{array}{l}\text { Allohu Akbar, Allohu Akbar } \\
\text { Allohu Akbar, walilla ilham }\end{array}$ \\
\hline d. & $\begin{array}{l}\text { Pamuga datang hartana } \\
\text { Muga-muga cita-cita } \\
\text { Rumasa beunghar ku dosa } \\
\text { Bahasa anu kawasa } \\
\text { Lebaran datang, } \\
\text { Minal aidzin walfaidzin } \\
\text { Umat Islam silih rangkul } \\
\text { Haksama pasusul-pasusul }\end{array}$ & g. & $\begin{array}{l}\text { Gedema takbir nu oyag } \\
\text { Dipirig eundeuma Dulag } \\
\text { Keur umat jadi pamapag } \\
\text { Numulang kana fitrahna } \\
\text { Lebaran datang, } \\
\text { Minal aidzin walfaidzin } \\
\text { Umat Islam silih rangkul } \\
\text { Haksama pasusul-pasusul }\end{array}$ \\
\hline
\end{tabular}


Dalam situasi budaya, Mang Koko merespon keadaan Hari Raya Idul Fitri (Lebaran) tahun 1038 Hijriah, atau tahun $1978,{ }^{19}$ dengan membuatkan lagu yang berjudul Lebaran. Lagu ini pada dasarnya menggambarkan kesibukan umat Islam dalam rangka merayakan Hari Raya Idul Fitri (Lebaran) yang penuh dengan nikmat serta pengampunan dari sesama umat. Untuk jelasnya di bawah ini contoh lirik lagunya:

Isi liriknya menggambarkan salah satu kebiasaan umat muslim dalam menjalankan ibadah puasa berikut zakat fitrah, dan saling maaf-memaafkan kesalahan di kala lebaran datang. Atas dasar hal itu tergambarkan bahwa Mang Koko memahami betul tentang makna lebaran.

\section{Membuat Karya karena ingin menampilkan karya baru Karawitan}

Dalam mencipta karena ingin menampilkan karya baru Karawitan Sunda, Mang Koko berupaya mengolah materi musik tradisi dan nontradisi sehingga karyanya mempunyai nafas baru (warna baru) dari karawitan Sunda yang telah ada sebelumnya. Dalam kategori ini Mang Koko merealisasikannya melalui keterampilan vokal dan tangan.

Melalui keterampilan vokal, Mang Koko menampilkan karya barunya dengan cara memberi warna baru terhadap karawitan Sunda tradisi, dan mengolah sebagian motif musik Barat. Dalam memberi warna baru karawitan Sunda, Mang Koko membuat lagu yang ornamennya merupakan hasil pengolahan dari beberapa ornamen karawitan vokal tradisi, sehingga lagu vokal karya Mang Koko tersebut berbeda dengan lagu-lagu Sunda tradisi sebelumnya. Lagulagu karya Mang Koko yang tergolong pada kategori ini antara lain:

Angkrek Japati, Bulan Langlayangan Peuting, Sariak Layung di Gunung, Gupay
Pileuleuyan, Pangantenan, dan lain sebagainya. Sementara dalam mengolah sebagian 'motif' lagu Barat, Mang Kokop membuat lagu vokal baru yang berpijak dari motif lagu Barat. Misalnya dari sebagian motif lagu To Me, Mang Koko olah kembali sehingga menjadi lagu Ka Abdi. Contoh liriknya sebagai berikut:

(a) Motif lagu To Me (diatonis) not to you not to him not to them not to those but to me

(b) Sebagian Lagu Ka Abdi yang motifnya diambil dari lagu To Me (pentatonis) Sanes ka bapa sanes ka juragan

Sanes ka itu ka ieu, tapi ngiler ka abdi

Demikian salah satu cara Mang Koko menampilkan karya baru lagu vokal dari hasil pengolahan sebagian motif lagu Barat, sehingga lagu tersebut tetap 'nyunda' (sesuai dengan nuansa musik vokal Sunda).

Dalam hal gending baik gending pengiring vokal (piringan) maupun gending macakal (instrumental) Mang Koko menampilkan karya barunya dengan dorongan untuk: 1) memperkaya musik pengiring suatu lagu yang telah memiliki musik pengiring sebelumnya; dan 2) melengkapi karya vokal.

\section{a) Memperkaya Musik Pengiring}

Dalam memperkaya suatu lagu yang memiliki musik pengiring sebelumnya, ada dua cara yang Mang Koko lakukan:

Pertama, membuat gending pengiring lagu vokal karya orang lain dalam gamelan pelog-salendro yang sebelumnya diiringi perangkat nongamelan pelog-salendro. Misalnya lagu Sumpah Suci yang biasanya diiringi Tarling (Gitar dan Suling), kemudian Mang Koko buatkan gending pengiring baru dalam perangkat gamelan pelog, sehingga lagu tersebut memiliki dua perangkat musik pengiring. Karya-karya 
lainnya dalam kategori ini adalah:

(1) Warung Pojok, laras madenda, karya Abdul Ajib, yang biasanya diiringi Tarling kemudian diiringi gamelan salendro (tahun 1972);

(2) Jali-jali, laras pentatonis Betawi, karya n.n., biasanya diiringi Gambang Kromong kemudian diiringi gamelan salendro (tahun 1970).

(3) Kunang-Kunang, laras degung, karya n.n., biasanya diiringi gamelan degung kemudian diiringi gamelan pelog (1977);

(4) Cikeruhan, laras salendro, karya n.n., biasanya diiringi perangkat ketuk tilu kemudian diiringi gamelan salendro (1977); dan sebagainya.

Dalam mewujudkan permainan gamelan untuk iringan lagu yang sebelumnya telah memiliki pola iringan tersendiri, pengolahannya berpedoman pada kenongan lagu vokal. Hal ini disebabkan karena permainan gamelan yang Mang Koko ciptakan dalam kategori ini sifatnya untuk melengkapi lagu vokal. Oleh sebab itu, kenongan gending pengiring harus sesuai dengan kenongan lagu vokalnya.

Kedua, mengolah kembali iringan lagu vokal yang sebelumnya menggunakan Kacapi, ke dalam perangkat gamelan pelog atau salendro. Misalnya lagu Bulan Langlayangan Peuting yang semula menggunakan waditra (instrument) kacapi, kemudian ditransfer ke dalam gamelan pelog. Karyakarya lainnya dalam kategori ini antara lain:

(1) Hariring Nu Kungsi Nyanding, laras pelog, iringannya ditransfer ke dalam gamelan pelog (1965);

(2) Turun Hujan Di pengkolan, laras pelog, iringannya ditransfer ke dalam gamelan pelog (1971);

(3) Gimiris Kasorenakeun, laras pelog, iringannya ditransfer ke dalam gamelan pelog (1967);
(4) Gupay Pileuleuyan, laras salendro, iringannya ditransfer ke dalam gamelan salendro (1962); dan sebagainya.

Dalam kategori ini Mang Koko menampilkan karya barunya dengan cara mentransfer permainan kacapi untuk iringan vokal ke dalam perangkat gamelan. Salah satu kekhasan musik pengiring vokal karya Mang Koko, baik dalam kacapi maupun dalam gamelan selalu diawali dengan gending macakal (intrumentalia). Gending macakal tersebut komposisi nadanya ada yang menggambarkan suasana lagu vokal, ada yang menggambarkan sebagian melodi lagu vokalnya, dan ada pula yang hanya sebagai pengisi kekosongan vokal.

\section{b) Melengkapi Karya Vokal}

Mencipta karena ingin melengkapi karya lagu vokal, maksudnya adalah membuat karya dalam bentuk gending, baik dalam waditra kacapi maupun dalam perangkat gamelan, untuk mengiringi lagu vokal yang Mang Koko ciptakan terlebih dahulu. Misalnya Mang Koko membuat lagu Sip Deh, karena lagu tersebut dianggapnya kurang lengkap, maka Mang Koko membuatkan gending pengiringnya. Dalam kategori ini, Mang Koko banyak menampilkan karya baru karawitan dalam bentuk gending, sebagai pelengkap karya lagu vokal yang ia buat sebelumnya.

Karya-karya Mang Koko dalam kategori 'Mencipta karena ingin menampilkan karya baru Karawitan', secara musikal termasuk karya baru karawitan. Tetapi secara bentuk masih mengakar pada tradisi karawitan Sunda, sehingga dengan demikian lahir istilah Wanda Anyar.

Di samping itu karawitan wanda anyar karya Mang Koko khususnya yang berkaitan dengan permainan gamelan pelogsalendro, secara tidak langsung berpengaruh terhadap perkembangan karawitan 
selanjutnya. Seperti munculnya permainan gamelan semacam karya

Mang Koko dalam pertunjukkan wayang golek Asep Sunandar Sunarya, lahirnya gending-gending kreasi baru dalam tari jaipongan, hadirnya degung wanda anyar karya Nano Suratno, dan sebagainya.

\section{Membuat Karya Karena Ingin Mendidik Generasi Penerus}

Sasaran Mang Koko dalam hal Mendidik Generasi Penerus adalah anak-anak Sekolah Dasar (SD), Sekolah Lanjutan Pertama (SLP), dan Sekolah Lanjutan Atas (SLA). Untuk kepentingan pendidikan kesenian di sekolah-sekolah tersebut, Mang Koko membuatkan lagu yang sesuai dengan kemampuan pisik dan psikis para siswanya. Untuk anak-anak SD misalnya, Mang Koko membuat lagu yang melodi dan liriknya disesuaikan dengan batas kemampuan anak-anak SD. baik ambahan suara (ambitus) maupun liriknya.

Untuk membedakan tingkat usia anak sekolah, dan sekaligus membedakan karyakarya yang akan dipelajarinya, Mang Koko membuat kelompok yang diberi nama:

a) Taman Bincarung untuk SD kelas I-IV;

b) Taman Cangkurileung untuk SD kelas V-VI;

c) Taman Setiaputra untuk SLP;

d) Ganda Mekar untuk SLA dan dewasa (orang Tua).

Karya-karya Mang Koko yang dibuat atas dasar kebutuhan untuk mendidik Generasi Penerus dalam berkesenian, sesuai dengan pengelompokan di atas, seluruhnya berupa lagu-lagu vokal. Lagu-lagu yang dibuat Mang Koko tersebut, sebagian sudah diterbitkan dalam bentuk buku, antara lain: Resep Mamaos, Bincarung, Cangkurileung jilid I-II untuk kelompok Taman Bincarung; buku Cangkurileung jilid III dan buku Sekar Mayang untuk kelompok Taman Cang- kurileung; Ganda Mekar dan Bentang Sulintang Taman Setiaputra; serta Kawih Sunda dan Manuskrip untuk kelompok SLA sampai orang dewasa (orang tua).

Sebagai gambaran berikut ini penulis beri contoh lagu untuk kelompok Taman Cangkurileung dan Taman Setiaputra. Lagu untuk Taman Cangkurileung sebagai berikut:

\section{Lagu Karatagan Urang Kampung \\ Urang Kampung, sisi gunung \\ Sepi jempling teu rame kawas di kota \\ Taya listrik, sepi pabrik \\ Arang langka, ka bioskop sandiwara \\ Tetep tigin, langka ulin \\ Temen wekel, usaha \\ Ngarolah taman, getol ibadah \\ Teu kalah ka carita}

Kesederhanaan liriknya adalah ungkapan kata-katanya menggunakan bahasa Sunda yang mudah dimengerti oleh anakanak dan isi liriknya menggambarkan keadaan kampung yang sempi keramaian, malah lebih berusaha mengolah tanahnya dan rajin beribadah, tanpa banyak cerita.

Dalam lagu-lagu untuk kelompok Taman Setiaputra, Mang Koko lebih cenderung memberi rasa estetis melodi dengan mengolah ritme dan ornamen, serta memperluas wawasan melalui lirik lagunya. Salah satu contoh lirik lagunya sebagai berikut:

\section{Tanah Sunda}

Tanah Sunda, gemah ripah

$\mathrm{Nu}$ ngumbara suka betah

Urang Sunda, sing toweksa

Nyangga dharma anu nyata

Seuweu Pajajaran, muga tong kasmaran

Sing tulaten jeung rumaksa

Miara pakaya, memang sawajibna

Geten titen rumawat tanah pusa ka

Dalam lirik lagu Tanah Sunda bahasa yang digunakannya lebih banyak kiasan, 


\section{Indung}

\section{Laras : Madenda \\ Surupan $\quad: 4=$ Tugu}

Geraisan : Antare

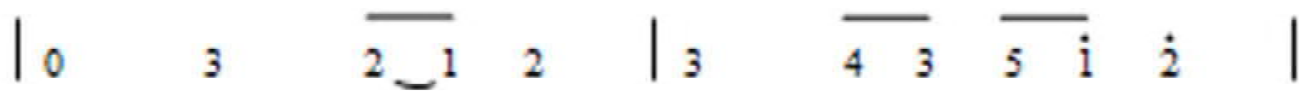

Duh in - ding nga - raksa nga-ja-ring

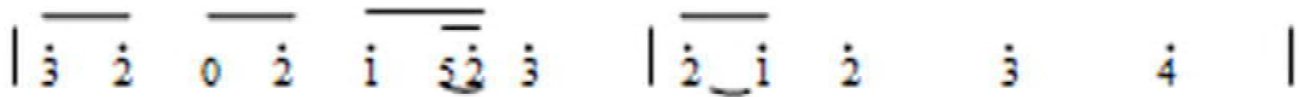

A-nak na-javoung-sing ma - tak pu - sing

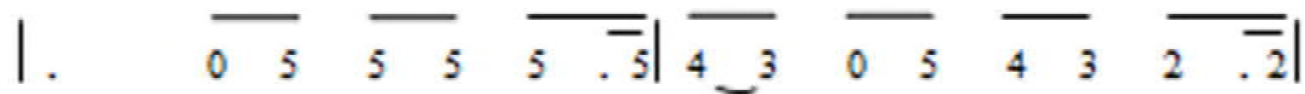

Hen-teu we-leh deudewh mi-ha-nza-ah a-

$|\overline{1 ـ 5}+\overline{01} \quad \overline{2 \overline{34}} 5 \quad| 3 \quad \overline{2 \_1} \quad \overline{3 \_} \quad 5 \quad$

sih di-mongmongjewng di - ti - ti - Mang

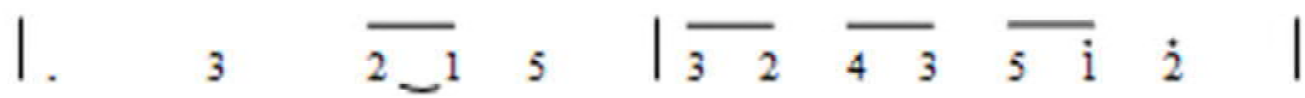

Duh in - dung nga-ping nga-da - ma-da - ma

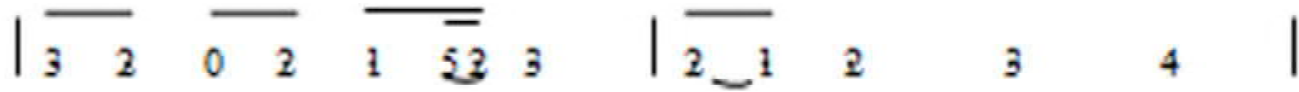
a-nak nga-mu-mu-le bu- ah ha - te

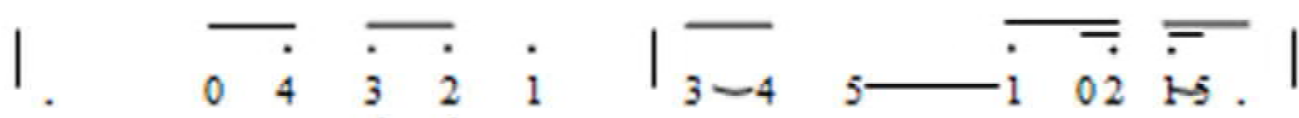

nga-jwngjwng twr ngu - gwng - ngugwng

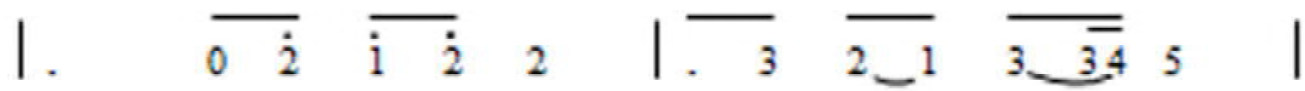

$a-n a k d i-j i \quad$ - awn $p u-p u-$ ton

|. $3 \quad \begin{array}{lllllll}2 \_1 & 5 & \text { I } & 3 & \overline{2 \_1} & 2\end{array}$

Dwh in - ding dwh in - ding

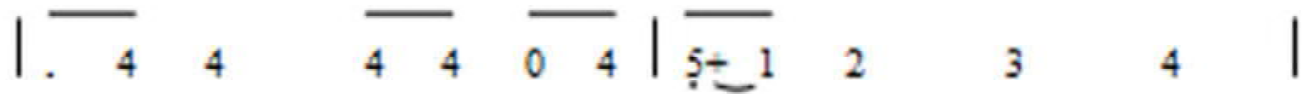

Ti-l lang $t i-t i$ nga-mong - mong a - nak

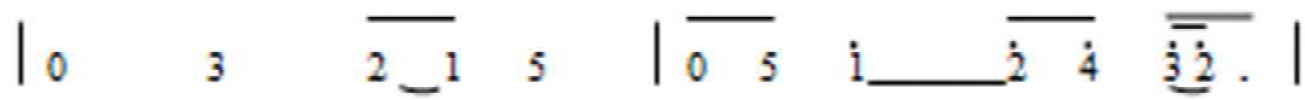

Dwh in - owng a-dinh in-ding

|. $\quad 3 \quad \overline{2 \_1}$ i $\mid \begin{array}{llll}5 \_\mathrm{i} & \dot{2} & \overline{\mathrm{i} \_5} & 5\end{array}$

Teu ben - dat nga - du - du - a 
Ditinjau dari teksnya, lagu di atas Mang Koko ciptakan dalam rangka mengekspresikan rasa kasih sayang seorang ibu terhadap anaknya. Dalam hal ini, Mang Koko curahkan perasaan hati seorang ibu dengan segala kelembutan dan kesabarannya lewat katakata dan nada, sehingga terbentuk sebuah karya yang ekspresif.

(b) Lagu ciptaan Mang Koko yang liriknya cibuat orang lain, seperti di bawah.
Ading Affandi dalam hal ini hanya menerjemahkan Adzan ke dalam bahasa Sunda. Kemudian hasilnya Mang Koko ekspresikan kembali ke dalam nada-nada yang berlaras mandenda surupan $5=\mathrm{L}$ dan $5=S$ hingga terwujud melodi lagu Adzan yang baru. Dalam contoh lagu Adzan, Mang Koko mengekspresikan lirik karya orang lain dengan tanpa dibebani pesanan dari penciptanya. Jadi tentang melodi lagunya benar-benar Mang Koko ekspresikan sendiri.

\section{Adzan}

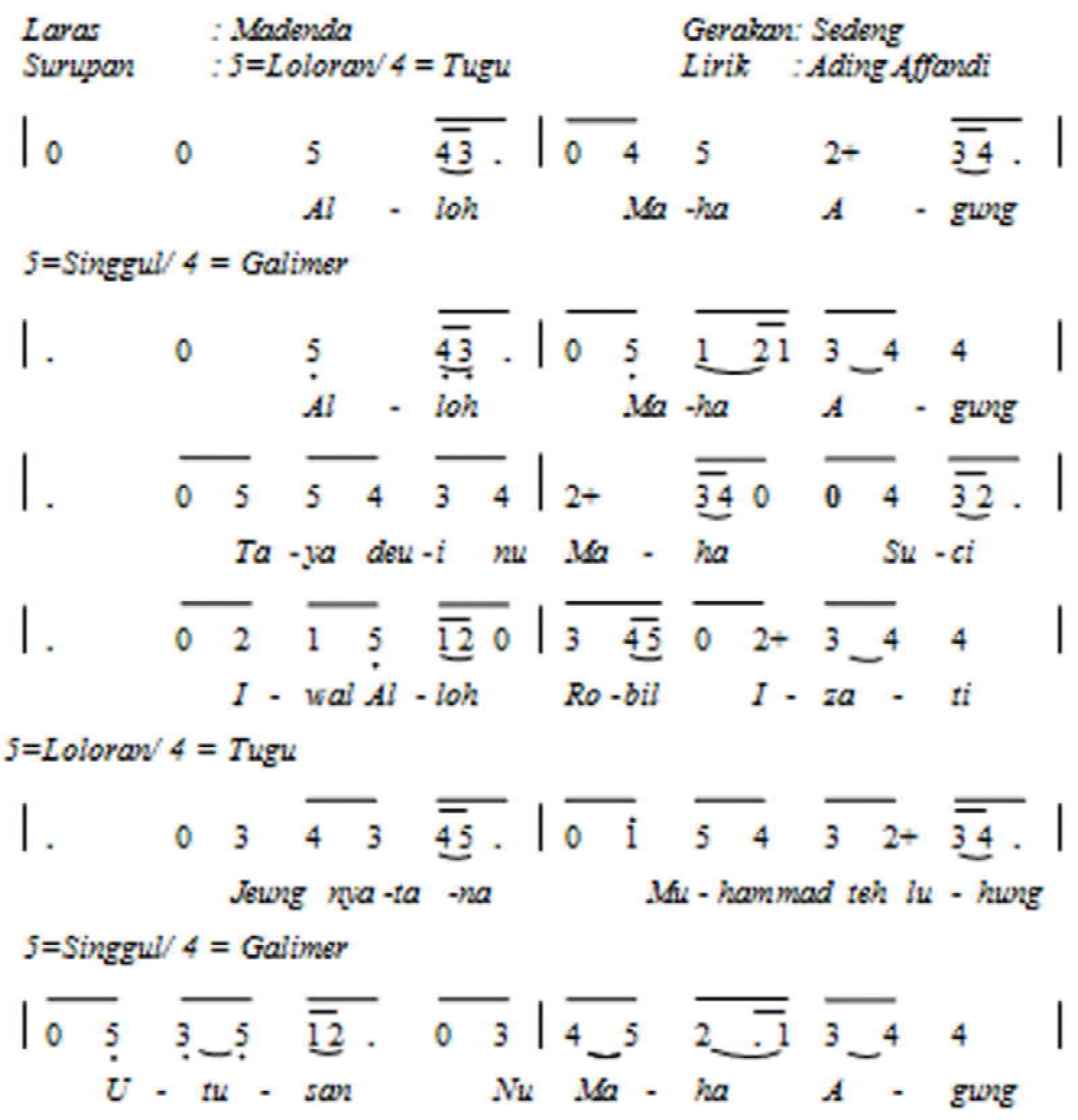


Dari segi musiknya, sekalipun kedua contoh lagu di atas tidak lepas dari tradisi (bentuk sekar alit), komposisi nadanya (melodinya) termasuk ciptaan baru; dalam arti tidak menggunakan melodi lagu yang telah ada. Oleh sebab itu, lagu-lagu yang diciptakan Mang Koko dalam kategori ini masih termasuk penciptaan yang berdasarkan ekspresi estetis murni.

\section{SIMPULAN}

Dari uraian di atas, menunjukkan bahwa eksistensi Mang Koko sebagai seniman kreatif dalam mengembangkan karawitan Sunda, tidak perlu disangsikan lagi. Hal ini terungkap dengan jelas dari kerjanya dalam melakukan penggalian dan penciptaan seni karawitan Sunda, yang hingga kini belum ada yang mengalahkan, baik jumlah maupun kualitas karyanya. Oleh sebab itu, wujud kreativitas Mang Koko melalui penggalian dan penciptaan yang dianggap menonjol dalam karawitan Sunda, secara fisik terealisasi melalui keterampilan vokal dan tangan. Kekuatan fisik Mang Koko, di samping terampil dalam bidang instrumen (kacapi dan gamelan pelog-salendro) serta vokal, juga mampu melahirkan karya-karya baru dari kedua bidang tersebut. Seperti lahirnya lagu-lagu vokal untuk anak-anak, remaja, dan dewasa (orang tua) berikut musik pengiringnya, termasuk hadirnya karyakarya seperti Jenakaan, kacapian, gamelan wanda anyar, dan drama swara atau gending karesmen adalah salah satu indikasi atas kekuatan fisik Mang Koko.

Dalam berkarya, Mang Koko selalu mencari nafas baru, dengan cara menggali potensi-potensi yang dimilikinya dan mengolah unsur-unsur musikal karawitan tradisi dan nontradisi ke dalam karyanya. Atas dasar hal itu lahirlah karya-karya baru karawitan Sunda yang mencirikan gaya
Mang Koko, yang menurut isitlah Mang Koko disebut karawitan 'Wanda Anyar'. Sedangkan yang berkaitan dengan kepeloporan Mang Koko dalam pengembangan karawitan Sunda, terdapat pada karya vokal berdialog, kacapian, dan gamelan wanda anyar.

Karya-karya Mang Koko yang dipersembahkan kepada apresiatornya melalui pertunjukan-pertunjukan, menjadi hal yang sangat berarti bagi kebutuhan hidup mereka terutama dalam mengisi kebutuhan batiniahnya. Inilah sebenarnya konsep Mang Koko yang diterapkan dalam berkesenian, sehingga apapun yang ia garap selalu sukses, walaupun tidak lepas dari tantangan dan rintangan.

Pada zamannya, seniman yang kreatif seperti Mang Koko terutama dalam berkarya sangatlah kurang. Oleh sebab itu kemungkinan untuk menempatkan Mang Koko sebagai central figure dalam hal kreativitas, sangatlah wajar. Hal ini terbukti bahwa setelah Mang Koko meninggal, karya-karya karawitan yang lahir dari generasi setelah Mang Koko, yang juga turut mewarnai perkembangan karawitan Sunda, secara esensial tidak lepas dari karawitan wanda anyar karya Mang Koko.

\section{Catatan AKhir}

${ }^{1}$ Teknik disinteruk-ditoel, digunakan karena posisi jari tangan kanan dalam keadaan nyintreuk (menjentik) dan posisi jari tangan kiri noel, yaitu menyentuh dengan ujung jari bagian bawah.

${ }^{2}$ Teknik dijeungkalan, digunakan karena posisi jari seperti menjengkal.

${ }^{3}$ Teknik beulit kacang, digunakan karena posisi jari kanan dan kiri seperti melilit.

${ }^{4}$ Teknik diranggeum, digunakan karena posisi jari semacam ngaranggeum (mengambil sesuatu dengan lima jari).

${ }^{5}$ Teknik dijambret, digunakan karena posisi jari kanan semacam menjambret (mengambil sesuatu dengan cepat).

${ }^{6}$ Dicaruk adalah tabuhan dua waditra yang saling terkait (bersahutan), misalnya saron I dan 
II, bonang dan demung (dalam irama tertentu).

${ }^{7}$ Dikemprang maksudnya menabuh dua buah nada baik satu gembyang (oktaf) maupun satu kempyung (akor) secara bersamaan, khususnya dalam waditra bonang dan rincik.

${ }^{8}$ Dibalung maksudnya menabuh balunganing (pola) gending atau melodi secara bersamaan.

${ }^{9}$ Dicacag maksudnya menabuh satu nada yang setiap periodenya 3 pukulan dengan teknik diredam (ditengkep) baik oleh tangan maupun dengan pemukulnya.

${ }^{10}$ Keleter maksudnya menabuh satu nada dengan dua pemukul dalam gerakan cepat, sehingga menghasilkan dua bunyi yang bersahutan (semacam tremolo dalam musik Barat), khususnya dalam waditra bonang dan rincik.

${ }^{11}$ Olah vokal adalah melatih pernafasan dan melatih suara-suara yang tinggi.

${ }^{12}$ Tarhim adalah membaca al-Quran sepuaspuasnya atau sekeras-kerasnya di Mesjid, menjelang sholat subuh (Koko Koswara, 2007:38).

13 Tembang Pupuh adalah sekar irama merdika yang melodinya masih sederhana.

${ }^{14}$ Tembang Ciawian adalah sekar irama merdika versi Ciawi.

15 Tembang Cianjuran Sekar irama merdika versi Cianjur

${ }^{16}$ Kawih Kepesindenan adalah lagu-lagu vokal yang biasa disajikan oleh sinden.

${ }^{17}$ Mang Koko Koswara Seniman Rancingeus, Swara Cangkurileung no.98, 1978, p.94.

${ }^{18}$ Adjum Djunaedi, Sekali Di Udara Teatap Di Udara Dari Masa Ke Masa, Swara Cangkurileung, no. 136, 1981.

${ }^{19}$ Swara Cangkurileung, no. 103,p. 215

\section{Daftar Pustaka}

Angga Kusumadinata, Rd., Machjar.

1950 Ringkesan Pangawikan Rinenggaswara. Jakarta: Noordhaff-Kolf N.V.

Angga Kusumadinata, Rd., Machjar.

1969 Seni Raras, Jakarta:Pradnja Paramita. Harsojo.
1988 Pengantar Antropologi, Bandung: Binacipta.

J. Moleong, Lexy.

1990 Metode Penelitian Kualitatif. Bandung: PT. Remaja Rosdakarya, Koentjaraningrat.

1990 Pengantar Ilmu Antropologi. Jakarta: PT. Rineka Cipta.

Rohendi Rohidi, Tjetjep.

2000 Kesenian Dalam Pendekatan Kebudayaan. Bandung: STISI Press.

Ruswandi, Tardi.

2007 Koko Koswara, Maestro Karawitan Sunda. Bandung: Kelir.

Soepandi, Atik dkk.

1977 Khasanah Kesenian Daerah Jawa Barat. Bandung: Proyek Penunjang Peningkatan Kebudayaan Indonesia Jawa Barat.

Sumardjo, Jakob.

2001 Seni Pertunjukan Indonesia. Bandung: STSI Press.

Supriadi, Dedi.

1994 Kreativitas, Kebudayaan \& Perkembangan Iptek, Bandung: Alfabeta. 